\title{
The Meaning Extensions of Human Body Part Terms in Thai Idioms
}

\author{
Nuntana Wongthai ${ }^{1}$ \\ ${ }^{1}$ Department of Linguistics, Srinakharinwirot University, Bangkok, Thailand \\ Correspondence: Nuntana Wongthai, Department of Linguistics, Srinakharinwirot University, Bangkok, \\ Thailand. E-mail: nuntana.w@gmail.com
}

Received: September 22, $2014 \quad$ Accepted: December 15, $2014 \quad$ Online Published: April 2, 2015
$\begin{aligned} & \text { doi:10.5539/ass.v11n9p146 } \\ & \text { URL: http://dx.doi.org/10.5539/ass.v11n9p146 }\end{aligned}$

\begin{abstract}
This paper presents the linguistics evidence from Thai idioms in support of the claim that our bodily experience plays a prominent role in the meaning construction. The data was collected from 29 Thai idiom books. The analysis is primarily based on metaphor, metonymy and chained metonymies in cognitive semantic approach. The data show that metaphor and metonymy are the motivating forces behind the semantic extension in the body part terms in Thai. However, most of the meaning extension of body part terms is found via metonymy. This fact supports the claim that metonymy is a more fundamental cognitive phenomena than metaphor. The most extended meaning found in the data is person. The body part term that its meaning is extended most is hand. This study also is a linguistic manifestation of Thai culture.
\end{abstract}

Keywords: body part terms, cognitive semantics, meaning extension, Thai idioms

\section{Introduction}

Humans always use the body part terms to refer to other things, for example, English has such expressions as the mouth of the river, the foot of the mountain or the hand of the clock. In Thai, the body part terms are also used in the extended meanings, for example, คอขวด khəo khùat (neck bottle) means the upper part of the bottle which is narrow. ปากซอย pàak sooy (mouth lane) means the entrance. This kind of usage is the comparison of the prominent attributes of the body parts and the part of the bottle and the lane. This makes the meanings of neck and mouth extend its meaning to mean a specific part of an entity. The body part terms are also found in idioms. In Thai, we are familiar with the idioms such as ชุบมือเปิบ chúp muu pəəp (soak hand eat), ได้หน้า dâay nâa (lose face), ปอกกล้วยเข้าปาก pòok klûay khâw pàak (peel banana enter mouth). The meanings of these body part terms are not used in the conceptual meanings but extended to be used in the metaphorical meanings. This study is aimed to discover the meanings of human body part terms used in idioms and to analyze the processes of meaning extensions of human body part terms in Thai idioms. The findings of study will reveal the importance of body to meaning construction.

\section{Objectives}

1. To study the meanings of human body part terms in Thai idioms.

2. To analyze the processes of meaning extensions of human body part terms in Thai idioms.

\section{Theoretical Framework}

This paper uses the theoretical ground of metaphorical relationships (Lakoff \& Johnson, 1980; Vyvyan, Melanie, 2006), metonymic relationships (Radden \& Kövecses, 1999) and chained metonymies (Hilpert, 2007) from the perspective of cognitive semantics as a framework to analyze the meaning extension encountered in the data.

\section{Methods}

In the study, the human body part terms are divided into 3 parts: upper part (including head, hair, face, brow, eye, ear, nose, cheek, mouth, chin, neck), middle part (including arm, hand, finger, shoulder, elbow, breast, chest, waist, belly), and lower part (including leg, calf, shin, knee, buttock, foot). The data were collected from 29 Thai idiom books. The data show that some body parts which are head, hand, buttock, and foot in Thai are called differently to mean the same. Head can be called hŭa (normal), sian, and klâaw (royal). Hand can be called muu (normal) ,koon (poetry or royal word). Buttock can be called kôn (normal), tùut (impolite). Foot can be called táaw (normal) and tiin (impolite). 
The data of body part terms in this study is limited to the external parts. From the data, there are 12 terms of the upper part, which are head (hǔa), head (š̉an), head (klâaw), face, hair, chin, brow, nose, neck, ear, mouth, and eye; 13 terms of the middle part, which are back, hand (mwu), hand (koon), elbow, waist, chest, breast, arm, fist, stomach, belly, shoulder, and finger; 8 terms of the lower part, which are leg, buttock (kôn), buttock (tùut), shin, foot (táaw), foot (tiin), knee, and calf. The total is 34 body part terms used in the study.

\section{Results}

The study shows that the meaning extensions of body part terms are varied. Table 1 presents the meaning extensions of body part terms.

Table 1 . The meaning extensions of body part terms

\begin{tabular}{|c|c|}
\hline body part terms & meaning extensions \\
\hline \multicolumn{2}{|r|}{ upper part } \\
\hline head (hǔa) & health, character, life, person, wisdom, taste, emotion, extremity \\
\hline head (šan) & wisdom \\
\hline head (klâaw) & wisdom \\
\hline face & honor, capability, interaction, character, person, appearance, action, front \\
\hline hair & important things, small issues, aging, \\
\hline chin & speaking manner, illness \\
\hline brow & action \\
\hline nose & interference, honor, dependence, thought, smelling, quickly knowing \\
\hline neck & important things, ignorance, speaking, drinking, person, action, sound, \\
\hline ear & intensity, hearing, obedience, understanding, person \\
\hline mouth & easiness, capability, speaking, eating \\
\hline eye & behavior, obstacle, important things, trust, logic malfunction, time, person, action, thought \\
\hline \multicolumn{2}{|r|}{ middle part } \\
\hline back & $\begin{array}{l}\text { originality, relationship, cooperation, cowardice, laziness, betrayal, seriousness, unseen } \\
\text { action, support }\end{array}$ \\
\hline hand (muu) & $\begin{array}{l}\text { character, intention, quantity, possession, power, capability, fight, cooperation, time, person, } \\
\text { action }\end{array}$ \\
\hline hand (kəon) & fight \\
\hline elbow & speaking, person \\
\hline waist & shape \\
\hline chest & protection, space for feeling/thought \\
\hline breast & burden \\
\hline arm & welcome, person \\
\hline fist & power, speaking \\
\hline stomach & eating, excretion, pregnancy, action \\
\hline belly & knowledge, happiness, memory, obesity \\
\hline shoulder & capability \\
\hline finger & Time, person, action \\
\hline \multicolumn{2}{|r|}{ lower part } \\
\hline $\operatorname{leg}$ & freedom, relationship, rules, person, walking, action \\
\hline buttock (kôn) & person, sitting, action \\
\hline buttock (tùut) & money, person, sitting, action \\
\hline shin & person \\
\hline foot (táaw) & person \\
\hline foot (tiin) & action, lowest part \\
\hline knee & energy, sadness, intimacy, power, \\
\hline calf & walking, leg, buttock, shin, foot, foot \\
\hline
\end{tabular}

From Table 1 the meanings extended can be categorized into 3 domains: human (including the relationships among them), entities, and time.

The study found that the meaning extensions of human body part terms are motivated through metaphor and metonymy. Metaphor is the understanding of one conceptual domain in terms of another conceptual domain whereas metonymy is the conceptual link between two entities in the same frame of reference. However, the 
findings show that not only single mapping of metaphor or metonymy that explain the meaning extension phenomena in the body part terms, do the serial conceptual mappings which highlight the interaction between metaphor and metonymy as well as chained metonymies also involve.

\subsection{The Metaphorical Mappings in Body Part Meaning Extension}

The findings show that from 33 body part terms, there are 22 words that their extended meaning motivated by metaphor from the conceptual domain of body parts to another different conceptual domains such as health, honor, thought, trust, operation. There are 8 terms in upper part, 11 terms in middle part, and 3 terms in lower part that the meanings are extended metaphorically. Table 2 shows the meaning extensions of body part terms motivated by metaphor.

Table 2 . The meaning extensions of body part terms motivated by metaphor

\begin{tabular}{|c|c|c|}
\hline $\begin{array}{l}\text { body part } \\
\text { terms }\end{array}$ & $\begin{array}{l}\text { meaning } \\
\text { extensions }\end{array}$ & linguistic expressions \\
\hline \multirow{5}{*}{$\begin{array}{l}\text { head } \\
\text { (hǔa) }\end{array}$} & & upper part \\
\hline & health & 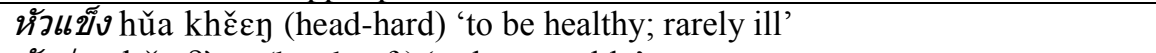 \\
\hline & & หัวอ่อน hǔa Pòon (head-soft) 'to be tractable' \\
\hline & character & หัวรัน hǔa rán (head-stubborn) 'to be bullheaded' \\
\hline & life & 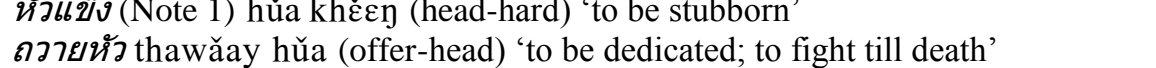 \\
\hline \multirow{11}{*}{ face } & & ได้หน้า dây nâa (receive-face) 'to get the favor of; to get a fame' \\
\hline & honor & $\begin{array}{l}\text { ฉีกหน้า chïik nâa (tear-face), หักหน้า hàk nâa (break-face) 'to humiliate' } \\
\text { ก้หน้า kûu nâa (regain-face) 'to save one's honor' }\end{array}$ \\
\hline & & ทำงามหน้า tham yaam nâa (do-pretty-face) 'to be dishonorable' \\
\hline & & ประมาทหน้า pramàat nâa (affront-face) 'to underestimate' \\
\hline & capability & เกินหน้า kəən nâa (surpass-face) 'to do excessively' \\
\hline & interaction & สู้หน้า sûu nâa, ประจันหน้า pracan nâa (fight-face) 'to confront' \\
\hline & & หันหน้าเข้าหากัน hăn nâa khâw hăa \\
\hline & & หน้าหนา nâa năa (face-thick) 'to \\
\hline & & หน้าเลื่อด nâa lûat (face-blood) 'to \\
\hline & character & คบคนให้ดูหน้า ขื้อผ้าให้ดูเนื้อ \\
\hline & & $\begin{array}{l}\text { khóp khon hây duu nâa súu phâa hây duu núa } \\
\text { (associate-people-give-look-face-buy-fabric-give-look-texture) 'to be careful } \\
\text { when choosing friends' }\end{array}$ \\
\hline \multirow{2}{*}{ hair } & $\begin{array}{l}\text { important } \\
\text { things }\end{array}$ & $\begin{array}{l}\text { รักเหายิงกว่าผม rák hăw yîn kwàa phǒm (love-lice-more-than-hair) 'sweat the } \\
\text { small stuff over the important one' }\end{array}$ \\
\hline & small issues & $\begin{array}{l}\text { เส้นผมบังภูเขา sên phǒm bạ phuukhăw (a strand of hair-hide-mountain) 'to } \\
\text { be unable to see the solution of a problem because of a small issue' }\end{array}$ \\
\hline \multirow{4}{*}{ nose } & interference & ยื่นจมูก yt̂n camùuk (pop-nose) 'to be nosy' \\
\hline & honor & เหยียบจมูก yiap camùuk (step on-nc \\
\hline & dependence & $\begin{array}{l}\text { ยื่มจมูกคนอื่นหายใจ yษm camùuk khon Pt̀mn hăaycay } \\
\text { (borrow-nose-others-breathe) 'to depend on others' }\end{array}$ \\
\hline & thought & จงจมูก cuun camùuk (tow-nose) 'to be convinced by others' \\
\hline \multirow{3}{*}{ neck } & $\begin{array}{l}\text { important } \\
\text { things }\end{array}$ & $\begin{array}{l}\text { คอขาดบาดตาย khวง khàat bàat taay (neck-torn-cut-die) 'a very important or } \\
\text { serious matter' }\end{array}$ \\
\hline & & โงแล้วอยากนอนเตียง คอเอียงแล้วอยากหนุนหมอน \\
\hline & ignorance & 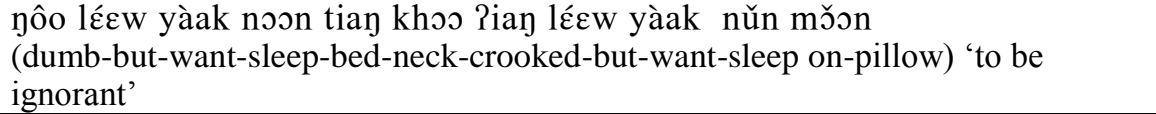 \\
\hline ear & intensity & หูฉี่ hǔu chïi (ear-hot) 'excessively' \\
\hline \multirow{2}{*}{ mouth } & ness & $\begin{array}{l}\text { ปอกกล้วยเข้าปาก pò̀k klûay khâw pàak (peel-banana-into-mouth) 'an easy } \\
\text { matter' }\end{array}$ \\
\hline & capability & $\begin{array}{l}\text { ปากไม่สินกลิ่นนำนม pàak mây sîn klîn náamnom } \\
\text { (mouth-without-breath-milk) 'not capable to do things' }\end{array}$ \\
\hline \multirow{4}{*}{ eye } & & เข้าเมืองตาหลิวต้องหลิวตาตาม \\
\hline & behavior & khâw muan taa liw tóoy liw taa taam \\
\hline & & $\begin{array}{l}\text { (enter-city-eye-squint-must-squint-eye-follow) 'to behave suitably to time at } \\
\text { place; When in Rome, do as the Romans do.' }\end{array}$ \\
\hline & obstacle & เรือล่มเมื่อจอดตาบอดเมื่อแก่ \\
\hline
\end{tabular}




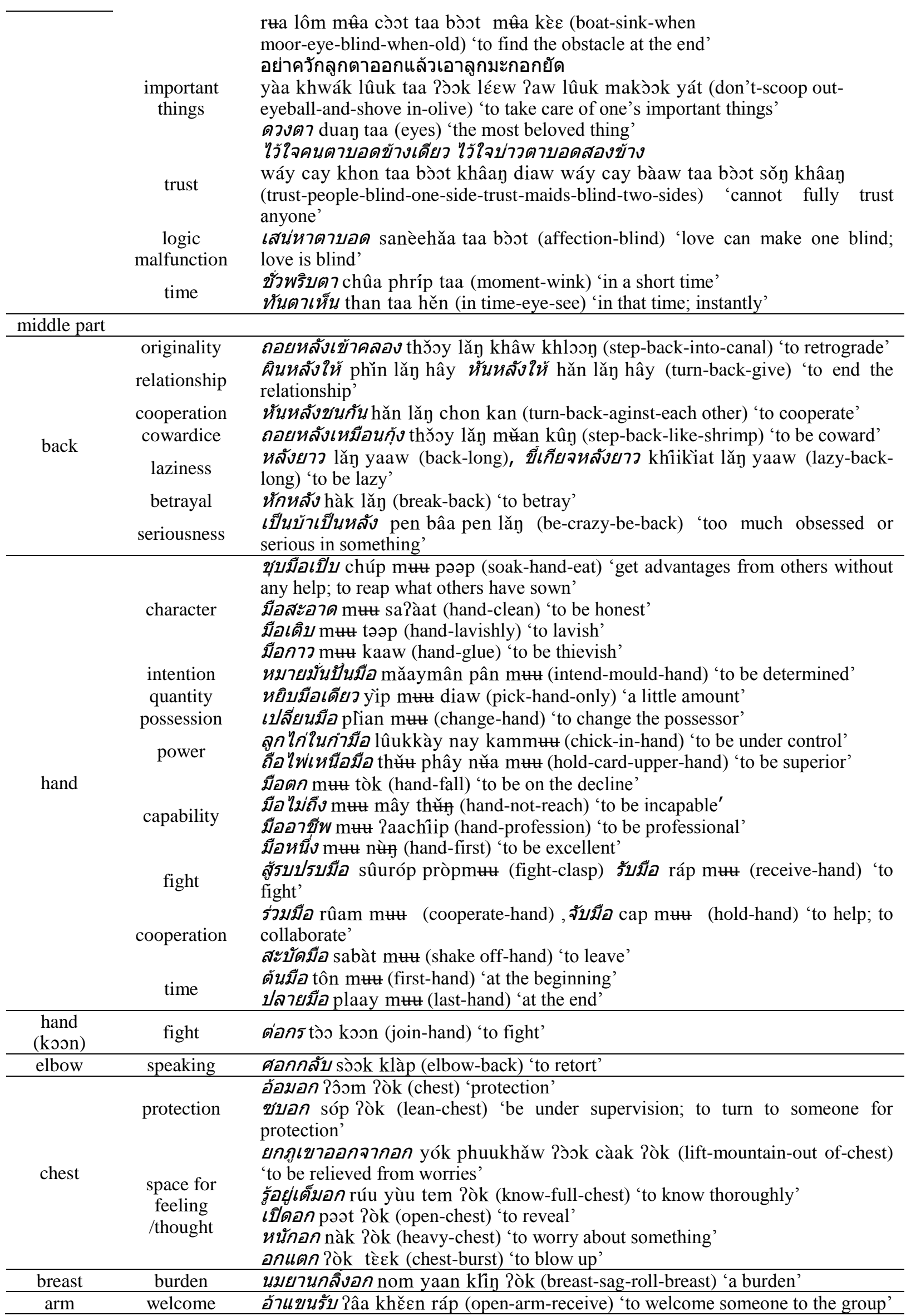




\begin{tabular}{|c|c|c|}
\hline fist & $\begin{array}{c}\text { power } \\
\text { speaking }\end{array}$ & $\begin{array}{l}\text { กำปันโต kampân too (fist-big) 'the big power' } \\
\text { กำปันเล็ก kampân lék (fist-small) 'the little power' } \\
\text { กำปันทุบดิน kampân thúp din (fist-pound-ground) 'to answer perfunctorily' }\end{array}$ \\
\hline belly & $\begin{array}{l}\text { knowledge } \\
\text { happiness } \\
\text { memory }\end{array}$ & 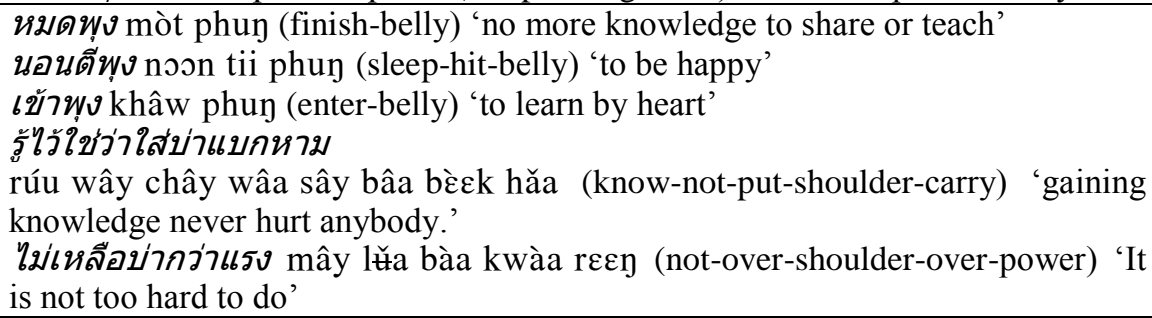 \\
\hline finger & & ลัดนิวมือ lát níw muแ (cut across-finger) 'a short time' \\
\hline & & \\
\hline leg & $\begin{array}{l}\text { freedom } \\
\text { relationship } \\
\text { rules }\end{array}$ & $\begin{array}{l}\text { ตรวนใส่ขา truan sày khăa (chain-put-leg) 'to lack freedom' } \\
\text { ถูกขา thùuk khăa (right-leg) ,เข้าขา khâw khăa (get along-leg) 'to get along } \\
\text { well' } \\
\text { สะดุดขาตัวเอง sadùt khăa tuaใey (stumble on-leg-own) 'break one's own rules' }\end{array}$ \\
\hline $\begin{array}{l}\text { buttock } \\
\text { (tùut) }\end{array}$ & money & หมดตูด mòt tùut (finish-buttock) 'to lose all the money' \\
\hline knee & power & $\begin{array}{l}\text { เข่าอ่อน khàw P̀̀n (knee-weak) 'to lack energy because of fear or walk for long } \\
\text { distance' } \\
\text { หักด้ามพร้าด้วยเข่า hàk dâam phráa dûay khàw } \\
\text { (break-handle-machete-with-knee) 'to exercise power over someone' } \\
\text { น่ำตาเช็ดหัวเข่า námtaa chét hǔakhàw (tear-wipe-knee) 'to be sad and } \\
\text { disappointed' } \\
\text { จับหัวเข่าพูด càp hǔakhàw phûut (touch-knee-talk) 'to talk intimately' }\end{array}$ \\
\hline
\end{tabular}

\subsection{The Metonymic Mappings in Body Part Meaning Extension}

The findings show that there are 26 words of which the extended meaning motivated by metonymy. The literal meanings of the body part terms and the extended meanings are related in a variety of relationships, such as PART FOR WHOLE, PART FOR PART, EFFECT FOR CAUSE, INSTRUMENT FOR ACTION, BODY PART FOR LOCATION. There are 12 terms in upper part, 7 terms in middle part, and 7 terms in lower part that the meanings are extended metonymically. Table 3 shows the meaning extensions of body part terms motivated by metonymy.

Table 3. The meaning extensions of body part terms motivated by metonymy

\begin{tabular}{|c|c|c|}
\hline $\begin{array}{l}\text { body part } \\
\text { terms }\end{array}$ & $\begin{array}{c}\text { meaning } \\
\text { extensions }\end{array}$ & linguistic expressions \\
\hline \multirow{6}{*}{$\begin{array}{l}\text { head } \\
\text { (hǔa) }\end{array}$} & & upper part \\
\hline & person & 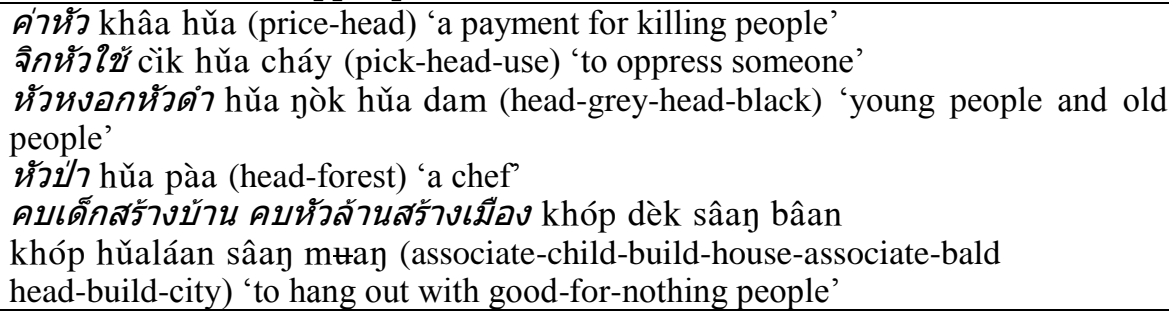 \\
\hline & wisdom & $\begin{array}{l}\text { สองหัวดีกว่าหัวเดียว sว̌ว hǔa dii kwàa hǔa diaw } \\
\text { (two-head-better-than-one-head) 'it's better to have other's opinion' } \\
\text { หัวหมอ hǔa mǒว (head-doctor) 'to be tricky' } \\
\text { หัวขี้เลื่อย hǔa khîilłây (head-saw dust) 'to be dumb' } \\
\text { หัวอ้ายเรือง (Note 2) hǔa Pâay ruay (head-Rueng (name)) 'to be able to solve the } \\
\text { problems' }\end{array}$ \\
\hline & taste & $\begin{array}{l}\text { หัวเก่า hǔa kàw (head-old) ,หัว โบราณ hǔa boraan (head-ancient) 'to } \\
\text { old-fashioned' } \\
\text { หัวใหม่ hǔa mày (head-new) 'to be modern' } \\
\text { หัวนอก hǔa nวิวk (head-foreign) 'to be a whitewash' }\end{array}$ \\
\hline & emotion & หัวเสีย hǔa sǐa (head-break down) 'to be frustrated' \\
\hline & extremity & เสียทองเท่าหัว ไม่ยอมเสียผัวให้ใคร \\
\hline
\end{tabular}


ša thoon thâw hǔa mây yoom sǐa phǔa hây khray

(lose-gold-equal-head-not-let-lose-husband-to-anyone) 'not exchange husband for treasure'

\begin{tabular}{|c|c|c|}
\hline $\begin{array}{l}\text { head } \\
\text { (š̌an, } \\
\text { klâaw) }\end{array}$ & wisdom & $\begin{array}{l}\text { ปวดเศียรเวียนเกล้า pùat sian wian klâaw } \\
\text { overwhelmed with problems' }\end{array}$ \\
\hline \multirow{3}{*}{ face } & person & $\begin{array}{l}\text { โดยถ้วนหน้า dooy thûan nâa (with-all-face) 'everybody' } \\
\text { หน้าม้า nâa máa (face-horse) 'a shill' } \\
\text { เปลี่ยนหน้า plian nâa (change face) 'not the same one' } \\
\text { หน้าอินทร์หน้าพรหม nâa in nâa phrom (face-Indra-face-Brahma) } \\
\text { people' } \\
\text { เห็นแก่หน้า hěn kèย nâa (see-for-face) 'to discriminate' }\end{array}$ \\
\hline & appearance & $\begin{array}{l}\text { หน้าขีไก่ nâa khîi kây (face-poop-chicken) 'to be very ugly' } \\
\text { หน้ากล้อ nâa klôว (face-round) 'a round face' } \\
\text { หน้าขาวเหมือนไข่ปอก nâa khăaw mǔan khày pòok (face-white-like-egg-peel) } \\
\text { 'smooth and white face' } \\
\text { หน้าข้าวตัง nâa khâaw tạ (face-rice crust) 'a scarred face' }\end{array}$ \\
\hline & action & $\begin{array}{l}\text { หน้าตูมเป็นดอกบัว nâa tuum pen dòokbua (face-bud-become-lotus), หน้าเป็น } \\
\text { ตวัก nâa pen tawàk (face- become-ladle), หน้างอเป็นม้าหมากรุก } \\
\text { nâa ทว pen máa màakrúk (face-bend-become-horse chess) 'to frown' } \\
\text { หน้าบานเป็นกระด้ง nâa baan pen kradôn (face-bloom-become-threshing basket) } \\
\text { 'to be delighted' } \\
\text { หน้าบูด nâa bùut (face-rotten) 'to be pettish' } \\
\text { หน้าตึง nâa tun (face-stiff) 'to show displeasure' }\end{array}$ \\
\hline hair & aging & 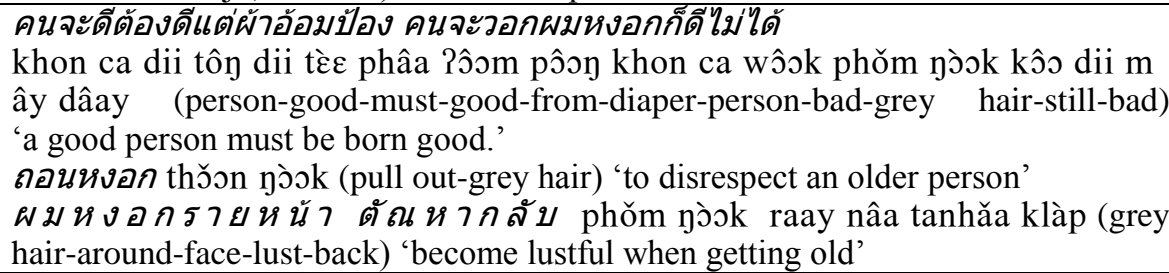 \\
\hline \multirow[t]{2}{*}{ chin } & $\begin{array}{l}\text { speaking } \\
\text { manner }\end{array}$ & ยานคาง yaan khaał (flabby-chin) 'to speak slowly' \\
\hline & illness & คางเหลือง (Note 3) khaay luăy (chin-yellow) 'to be seriously ill' \\
\hline brow & action & $\begin{array}{l}\text { ผูกคิววนิวหน้า phùuk khíw nîw nâa (tie-brow-frown-face) 'to show dissatisfaction } \\
\text { on face' }\end{array}$ \\
\hline nose & smelling & $\begin{array}{l}\text { ฉุนขึนจมูก chǔn khûn camùuk (tang-up-nose) 'to have a tangy smell' } \\
\text { เตะจมูก tè camùuk (kick-nose) 'to have a strong smell' }\end{array}$ \\
\hline \multirow{5}{*}{ neck } & speaking & $\begin{array}{l}\text { คอเป็นเอ็น khoง pen Pen (neck-become-tendon) 'to argue stubbornly' } \\
\text { ดักคอ dàk khoง (trap-neck) 'to speak before another; to impede' } \\
\text { ขัดคอ khàt khoว (obstruct-neck) 'to heckle' }\end{array}$ \\
\hline & $\begin{array}{l}\text { drinking } \\
\text { (alocohol) }\end{array}$ & 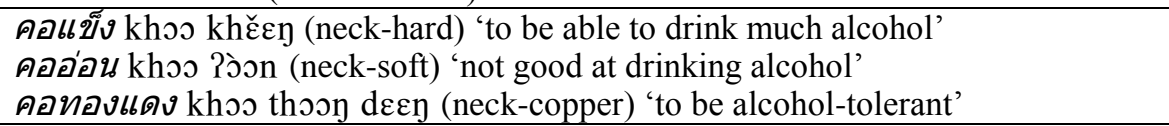 \\
\hline & person & 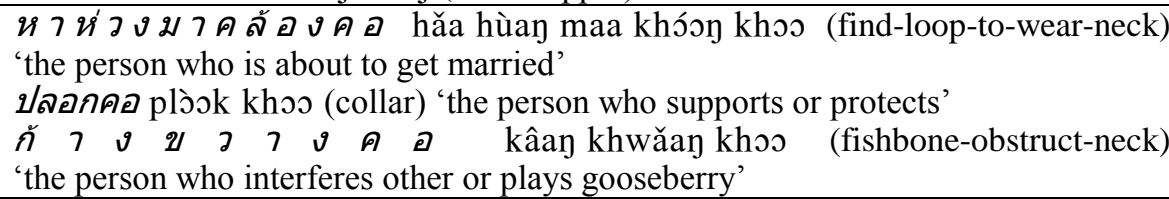 \\
\hline & action & $\begin{array}{l}\text { คำคอ khám khoว (support-neck) 'to be in a position of unwilling act' } \\
\text { ชูคอ chuu khoว (lift-neck) 'to be arrogant' } \\
\text { หักคอ hak khวo (break-neck) 'to force someone to do something' }\end{array}$ \\
\hline & sound & ลูกคอ lûuk khэง (child-neck) 'coloratura' \\
\hline \multirow[t]{2}{*}{ ear } & hearing & $\begin{array}{l}\text { เข้าหู khâw hǔu (enter-ear) 'to hear' } \\
\text { เข้าหูซ้ายทะละหูขวา khâw hǔu sáay thalú hǔu khwǎa } \\
\text { (enter-ear-left-out-ear-right) 'to listen but not retain any information' } \\
\text { ทำหูทวนลม tham hǔu thuan lom (make-ear-upwind) 'to pretend not to hear' } \\
\text { หนาหู nǎa hǔu (thick-ear) 'heard immensely' }\end{array}$ \\
\hline & person & คู่หู khûu hǔu (pair-ear) 'a buddy’ \\
\hline mouth & speaking & นำท่วมปาก náam thûam pàak (flood-mouth) "cannot tell the truth; to be \\
\hline
\end{tabular}


tongue-tied'

ปากเปียกปากแฉะ pàak pìak pàak chèc (mouth-wet-mouth-damp) 'to grumble' ปากสว่าง pàak sawàay (mouth-bright) 'to disclose other's secret'

ปากกรรไกร pàak kankray (mouth-scissors) 'to speak badly'

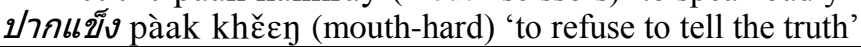

ตามใจปากมากหนี่ taam cay pàak mâak nîi (spoil-mouth-full of- debt) 'to spend a lot on food'

eating เปรี้ยวปาก prîaw pàak (sour-mouth) 'to crave for food'

อดอยากปากแห้ง ใòt yàak pàak hêعy (starve-mouth-dry) 'to be famished; nothing to eat'

ถูกปาก thùuk pàak (right-mouth) 'to be delicious'

ตาบอดคลำช้าง taa bòst khlam cháay (blind-grope-elephant) 'the person who knows only one side of the story but he thinks he knows the whole story.'

person ตาบอดได้แว่น taa bòot dâay wêعn (blind-get-eyeglasses) 'a person who gets something useless'

ขวัญตา khwăn taa (spirit-eye) 'a beloved woman' ตากล้อง taa klôวท (eye-camera) 'a photographer'

eye

ตาเป็นมัน taa pen man (eye-become-shiny) 'to stare with desire'

ตาเล็กตาน้อย taa lék taa nóวy (eye-small-eye-little) 'to show affection'

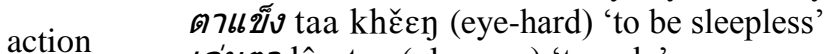

เล่นตา lên taa (play-eye) 'to ogle'

จับตา càp taa (catch-eye) 'to look at something attentively'

ชายตา chaay taa (edge-eye) 'to glance'

\section{middle part}

จับมือใครดมไม่ได้ cáp mu khray dom mây dâay

(hold-hand-anyone-smell-unable) 'unable to find the guilty'

มัดมือชก mát m世廿 chók (bind-hand-punch) 'to force someone to do something'

person ด อ ก ไ้ ม้ ใก ล้ มื อ dòok máay klây muu (flower-near-hand)

'a worthless woman'

มือมืด mயu mûut (hand-dark) 'an unknown guilty'

มือที่สาม m世 thîi săam (hand-third) 'a person who intervenes other's business'

ตบมือข้างเดียวไม่ดัง tòp mษ khâay diaw mây day (clap-one-hand-not-loud)

hand 'doing something alone may not succeed; it takes two to tango.'

มือเป็นระวิง muu pen rawin (hand-become-reel) 'to work without rest'

จับปลาสองมือ càp plaa sว̌oy m世u (catch-fish-two-hand) 'to work or do many

action things at the same time may cause mistakes'

มือไม่พายเอาเท้าราน้ำ

muu mây phaay ?aw tháaw raa náam

(hand-not-row-put-feet-drag-river)

'not help and interfere others'

ขึ้นไม้ขึ้นมือ khûn máay khûn muu (up-wood-up hand) 'to point at someone's face when getting angry'

\begin{tabular}{|c|c|c|}
\hline elbow & person & $\begin{array}{l}\text { กินนำใต้ศอก kin náam tâay sòok (drink-water-under-elbow) } \\
\text { 'to become a mistress' }\end{array}$ \\
\hline waist & shape & $\begin{array}{l}\text { เอวเท่ามดตะนอย Rew thâw mót tan๖วy (waist-same size as-wasp ant) เอวบาง } \\
\text { ร่างน้อย ใew baan râan nóวy (waist-thin-body-small) 'to be slim' }\end{array}$ \\
\hline arm & person & 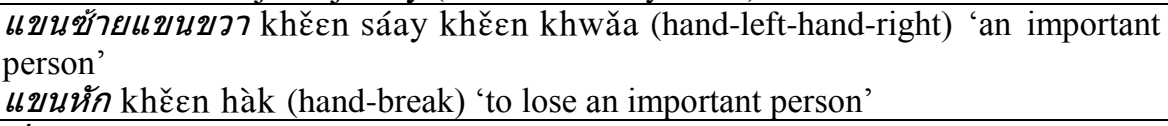 \\
\hline \multirow{5}{*}{ stomach } & eating & $\begin{array}{l}\text { ฝากท้อง fàak thó⿰习 (deposit-stomach) 'to rely on someone else's food' } \\
\text { รองท้อง roวy thóวy (support-stomach) 'to grab a bite' } \\
\text { เอาน้ำลูบท้อง ใaw náam lûup thóon (bring-water-grope-stomach) 'to relieve } \\
\text { hunger with water' }\end{array}$ \\
\hline & excretion & ท้องเดิน thว์ว dəən (stomach-walk) 'to have diarrhea' \\
\hline & pregnancy & 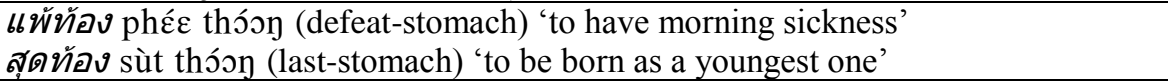 \\
\hline & & 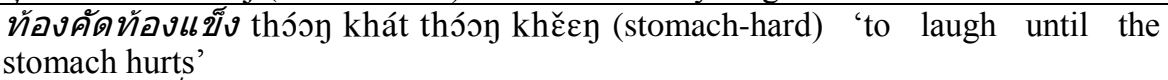 \\
\hline & action & $\begin{array}{l}\text { หายใจ ไม่ทั่วท้อง hăay cay mây thûa thóon (breathe-not-thorough-stomach) } \\
\text { 'to be nervous' } \\
\text { กินปูนร้อนท้อง kin puun róon thóวy (eat-lime-hot-stomach) } \\
\text { 'to behave suspiciously' }\end{array}$ \\
\hline
\end{tabular}




\begin{tabular}{|c|c|c|}
\hline belly & obesity & ลงพุง lon phun (down-belly) 'too much obese' \\
\hline \multirow[t]{2}{*}{ finger } & person & 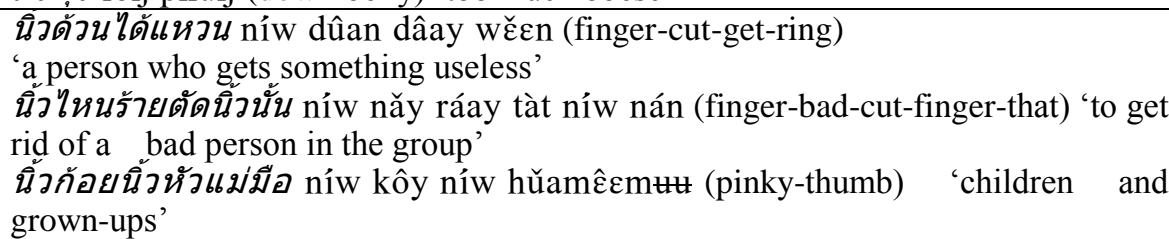 \\
\hline & action & $\begin{array}{l}\text { ชี่นิว chíi níw (point-finger) 'to act like a boss' } \\
\text { กระดิ้กนิว kradik níw (twiddle-finger) 'to command others to do things' } \\
\text { ยกินิว yók níw (raise-finger) ‘to show admiration' } \\
\text { เกี่ยวก้อย kiaw kôy (cross-pinky) 'to show intimacy' }\end{array}$ \\
\hline & & lower part \\
\hline \multirow{3}{*}{ leg } & person & $\begin{array}{l}\text { ขา khǎa (leg) 'a person who is needed to complete a group activity' } \\
\text { ขาจร khǎa coon (leg-casual) 'a irregular customer' } \\
\text { ขาประจำ khăa pracam (leg-regular) 'a frequenter' }\end{array}$ \\
\hline & walking & $\begin{array}{l}\text { ง่อยเปลี่ยเสียขา yวิวy plîa sía khǎa (lame-lose-leg) 'to be handicapped; unable to } \\
\text { walk' }\end{array}$ \\
\hline & action & $\begin{array}{l}\text { พอก้าวขาก็ลาโรง phoง kâaw khăa kôs laa roop } \\
\text { 'to arrive or do things very late' } \\
\text { ขัดขา khàt khăa (obstruct-leg) 'to interrupt' }\end{array}$ \\
\hline \multirow{3}{*}{$\begin{array}{c}\text { buttock } \\
\text { (kôn) }\end{array}$} & person & $\begin{array}{l}\text { ไฟลนก้น fay lon kôn (fire-under-buttock) 'a person who does things at last } \\
\text { minute' }\end{array}$ \\
\hline & sitting & $\begin{array}{l}\text { ก้นร้อน kôn róon (buttock hot) 'unable to sit long' } \\
\text { ก้นหนัก kôn nàk (buttock heavy) 'to be able to sit for a long time' } \\
\text { สะบัดก้น sabàt kôn (shake off-buttock) 'to leave immediately because of } \\
\text { frustration' }\end{array}$ \\
\hline & action & ก้นกระดก kôn kradòk (buttock-raise) 'to be haughty and snooty' \\
\hline \multirow{3}{*}{$\begin{array}{l}\text { Buttock } \\
\text { (tùut) }\end{array}$} & person & $\begin{array}{l}\text { ตูด ไว tùut way (buttock-quick) 'a credulous woman' } \\
\text { ไฟจุกตูด fay cùk tùut 'fire-under-buttock' 'a person who does things at last } \\
\text { minute' }\end{array}$ \\
\hline & sitting & ตูดร้อน tùut róon (buttock-hot) 'unable to sit long \\
\hline & action & $\begin{array}{l}\text { ตูดกระดก ครกกระเดื่อง tùut kradòk khrók kradùan (buttock-raise-mortar-shake) } \\
\text { 'to be haughty and snooty' }\end{array}$ \\
\hline shin & person & 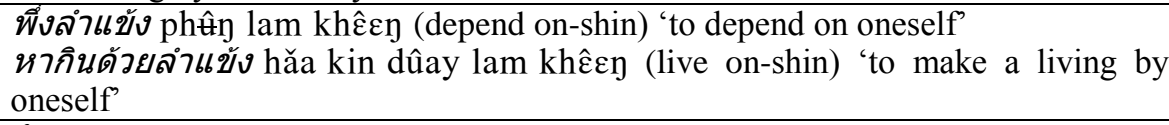 \\
\hline $\begin{array}{c}\text { foot } \\
\text { (tháaw) }\end{array}$ & person & $\begin{array}{l}\text { วัดรอยเท้า wát rooy tháaw (measure-footprint) 'to compete with someone higher. } \\
\text { แกว่งเท้าหาเสี้ยน kwย่̀ท tháaw hăa sîan (swing-foot-find-thorn) 'get oneself in } \\
\text { trouble' } \\
\text { ทุ่มหินใส่เท้า thûm hǐn sày tháaw (throw-stone-to-foot) 'someone who causes } \\
\text { trouble to others but ends up getting in trouble themselves' }\end{array}$ \\
\hline \multirow{2}{*}{$\begin{array}{l}\text { foot } \\
\text { (tiin) }\end{array}$} & person & 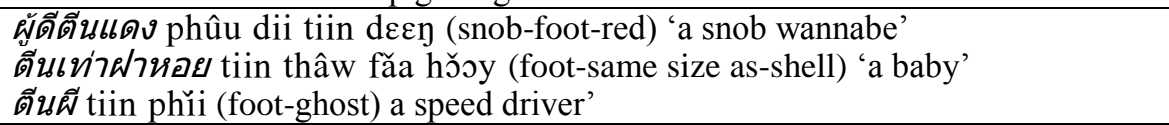 \\
\hline & action & $\begin{array}{l}\text { คันตีน khan tiin (itch-foot) 'to want to kick someone' } \\
\text { เหยียบเต่าเต็มตีน yiap tàw tem tiin (step on-turtle-full-feet) 'to do something } \\
\text { attentively' }\end{array}$ \\
\hline \multirow{2}{*}{ calf } & walking & ทอดน่อง thวิวt nôวy (let go-calf) 'to walk slowly; to stroll' \\
\hline & leg & น่องทอง nôวท thวoท (calf-gold) 'a smooth and beautiful leg' \\
\hline
\end{tabular}

\subsection{The Interaction between Metaphor and Metonymy in Body Part Meaning Extension}

The findings show that there are 6 words, 4 terms in upper part, 1 term in middle part, and 1 term in lower part that their extended meaning motivated by the interaction between metaphor and metonymy, which Goosens (1995) coined the term 'metaphtonymy', an interplay of metonymies and metaphors in the construction of meaning. With respect to such series of mappings, the findings show that the metonymies based on metaphors are rare according to Taylor (2002), Goossens (2002), Hilpert (2007). The findings show that there are two words which are face and foot )tiin( that the metonymies based on metaphors. Table $4-9$ show the meaning extensions of body part terms motivated by the interaction between metaphor and metonymy. 
Table 4. The meaning extensions of face

\begin{tabular}{ccl}
\hline body part terms & meaning extensions & linguistic expressions \\
\hline face & front & คว่ำหน้า khwâm nâa (overturn-face) 'to floor the top part' \\
\hline
\end{tabular}

The conceptual metaphor is OBJECTS ARE HUMAN BEINGS. The conceptual metonymy is PART FOR REGION. The OBJECTS ARE HUMAN BEINGS metaphor is extended to a specific region of object via metonymy.

Table 5. The meaning extensions of nose

\begin{tabular}{ccc}
\hline body part term & meaning extensions & linguistic expressions \\
\hline nose & quickly knowing & จมูกไวเหมือนมด camùuk way mǔan mót (nose-quick-like-ant) \\
& 'to be fast in knowing something'
\end{tabular}

The conceptual metaphor is THE ORGAN FOR PERCEPTION FOR PERCEPTION. The conceptual metonymy is KNOWING IS SMELLING. The ORGAN FOR PERCEPTION FOR PERCEPTION metonymy is extended to abstract meaning 'quickly knowing' via metaphor.

Table 6. The meaning extensions of ear

\begin{tabular}{|c|c|c|}
\hline body part term & meaning extensions & linguistic expressions \\
\hline \multicolumn{3}{|r|}{$\mathrm{Up}$} \\
\hline ear & obedience & $\begin{array}{l}\text { เป่าหู pàw hǔu (blow-ear) 'to abet' } \\
\text { ฟังหูไว้หู fạ hǔu wáy hǔu (listen-ear-keep-ear) 'to listen and } \\
\text { consider before believe' } \\
\text { หูเบา hǔu baw (ear-soft) 'to be credulous' } \\
\text { หูหนัก hǔu nàk (ear-heavy) 'to be hard to believe' } \\
\text { ก ข ไม่กระดิกหู kอง khว̌ว mây kradik hǔu (a b-not-wiggle-ear) } \\
\text { 'to be illiterate' } \\
\text { กระดิกหู (wiggle-ear) kradik hǔu 'to understand clearly' }\end{array}$ \\
\hline
\end{tabular}

The conceptual metonymy is THE ORGAN FOR PERCEPTION FOR PERCEPTION. The conceptual metaphors are THE OBEDIENCE IS HEARING and THE UNDERSTANDING IS HEARING. The ORGAN FOR PERCEPTION FOR PERCEPTION metonymy is extended to abstract meaning 'understanding' via metaphor.

Table 7. The meaning extensions of eye

\begin{tabular}{|c|c|c|}
\hline body part term & meaning extensions & linguistic expressions \\
\hline eye & thought & 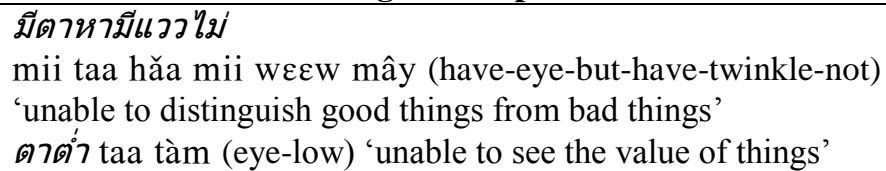 \\
\hline
\end{tabular}

The conceptual metonymy is THE ORGAN FOR PERCEPTION FOR PERCEPTION. The conceptual metaphor is THINKING IS SEEING. The ORGAN FOR PERCEPTION FOR PERCEPTION metonymy is extended to abstract meaning 'thinking' via metaphor.

Table 8. The meaning extensions of back

\begin{tabular}{ccl}
\hline body part term & meaning extensions & \multicolumn{1}{c}{ linguistic expressions } \\
\hline back & unseen action & $\begin{array}{l}\text { ปิด ทองหลัง พระ pit thoon lăy phrá (attach-gold-behind-Buddha } \\
\text { statue) 'to do a thankless job' }\end{array}$ \\
\hline
\end{tabular}

The conceptual metonymy is BACK PART FOR LOCATION. The conceptual metaphor is UNSEEN ACTION IS BACK LOCATION. The BACK PART FOR LOCATION metonymy is extended to abstract meaning 'unseen action' via metaphor. 
Table 9. The meaning extensions of foot

\begin{tabular}{ccc}
\hline body part term & meaning extensions & linguistic expressions \\
\hline foot $) \operatorname{tiin}($ & lowest part & ปลายตีน plaay tiin (end-foot) 'the lowest part of the bed' \\
\hline
\end{tabular}

The conceptual metaphor is OBJECTS ARE HUMAN BEINGS. The conceptual metonymy is PART FOR REGION. The OBJECTS ARE HUMAN BEINGS metaphor is extended to a specific region of object via metonymy.

The findings in this section support the MIND-as-BODY metaphor by Sweetser (1990), where the physical domain (perceptual domain) is mapped onto the mental domain.

\subsection{The Chained Metonymies in Body Part Meaning Extension}

The extended meanings of body part terms are also constructed through chained metonymies, which are metonymies that involve multiple conceptual shifts (Hilpert, 2007). The example of chained metonymies is as follows.

You'll find better ideas than that in the library. (Reddy 1979: 309 in Hilpert, 2007)

$$
\text { Ideas } \rightarrow \text { words } \rightarrow \text { pages } \rightarrow \text { books }
$$

The example above explains that ideas are expressed in words, printed on pages within books, which are found in libraries.

Table 10. The meaning extensions of neck

\begin{tabular}{|c|c|c|}
\hline body part terms & meaning extensions & linguistic expressions \\
\hline neck & taste & 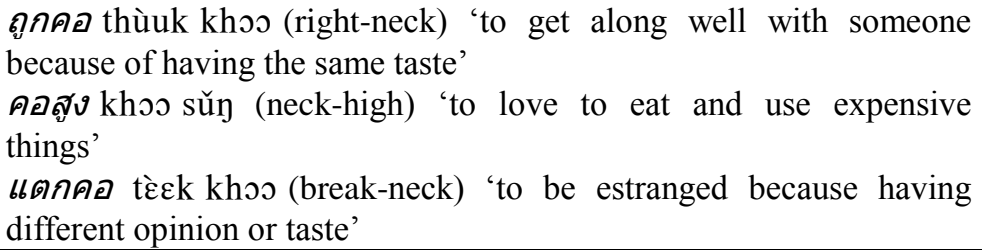 \\
\hline
\end{tabular}

NECK FOR EATING; EATING FOR TASTE; Neck $\rightarrow$ eating $\rightarrow$ taste

We can see that the chained metonymies are different from metonymy because they involve more than one conceptual shift. In the above example, only single metonymic mapping from books (in the libraries) onto ideas are insufficient. However, Hilpert (2007) said that nothing in principle disallows a single metonymic mapping but the chained metonymies have advantage to break up complex conceptual mappings into simple, well-motivated mapping with a strong experiential basis.

The findings show that there are 2 words, which are neck and back, that their extended meaning motivated by the chained metonymy. Table 10 shows the meaning extensions of body part terms motivated by the chained metonymy.

Table 11. The meaning extensions of back

\begin{tabular}{|c|c|c|}
\hline body part terms & meaning extensions & linguistic expressions \\
\hline back & support & $\begin{array}{l}\text { เดินตามหลังผู้ใหญ่หมาไม่กัด } \\
\text { dəวn taam lăy phûuyày măa mây kàt } \\
\text { (walk-follow-adult-dog-not-bite) 'It's safe to follow adults' } \\
\text { behaviors.' } \\
\text { หนุนหลัง nǔn lăy (support back) 'to abet; to back up' }\end{array}$ \\
\hline
\end{tabular}

BACK PART FOR LOCATION; PLACE FOR ACTION (Hilpert, 2007: 10); Back $\rightarrow$ location $\rightarrow$ action 


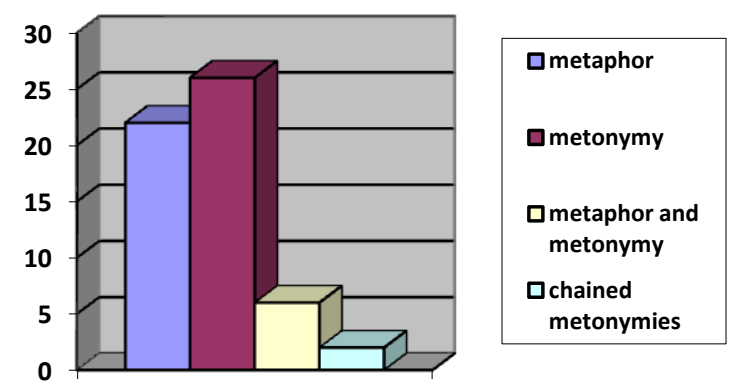

Figure 1. The processes of meaning extensions of human body part terms in Thai idioms

Figure 1 shows that the process of meaning extension found the most in human body part terms is metonymy. This fact supports the claim that metonymy is a more fundamental cognitive phenomena than metaphor (Panther \& Radden, 1999).

\section{Discussion}

In this study, I explore the importance of body to the emergence of meaning. The data taken from Thai idioms that contain the body part terms reveal that meanings emerge from bodily experiences. The findings suggest that metaphor and metonymy are the important cognitive tools in the meaning extension process. Some examples in the study involve metaphor only, while others involve only metonymy. However, most of the meaning extension of body part terms is found via metonymy. This fact supports the claim that metonymy is a more fundamental cognitive phenomena than metaphor (Panther \& Radden, 1999). There are 6 words that their extended meaning motivated by the interaction between metaphor and metonymy, which Goosens (1995) coined the term 'metaphtonymy', an interplay of metonymies and metaphors in the construction of meaning. With respect to such series of mappings, the findings show that the metonymies based on metaphors are rare according to Taylor (2002), Goossens (2002), Hilpert (2007). The findings show that there are two words which are face and foot that the metonymies based on metaphors.

The most extended meaning found in the data is person. This meaning is found in 14 body part terms which are head, face, neck, eye, hand, elbow, arm, finger, leg, buttock (kôn), buttock (tùut) ,shin, foot (táaw), foot (tiin). Those terms are in every part of human body. The body part term that its meaning is extended most is hand. The meanings of hand are extended to 11 semantic domains. It may be because people use their hands to do many kinds of activities in everyday life.

The finding reflects Thai culture in at least 4 aspects which are religious belief, play, martial art, and way of living. In religious belief, it reflects in the idiom หน้าอินทร์หน้าพรหม nâa in nâa phrom (face-Indra-face-Brahma) 'powerful people'. Indra, the great diety of Hinduism; Brahma (four-faced god) which discloses that Thai religion is partial Brahmanism. Thai people partially believe in animism, which pre-dated the arrival of Buddhism, considered as the major religion in Thailand. The fact relates to the research results in the conceptual metaphors of death in Thai (Wongthai, 2012) which showed that Thai people believe that death is only the end of the body state but the spirit still exists for the cycle of rebirth. This kind of belief originates from Brahmanism.

In play, some idioms reflect the popular play in Thai culture, chess in หน้างอเป็นม้าหมากรุก nâa yoo pen máa màakrúk (face-bend- become-horse chess) 'to frown' and cards in ถือไพ่เหนือมื่อ thǔu phây nǔa mü (hold-card-upper-hand) 'to be superior'. In martial art, it reveals that Thai boxing or Muay Thai which becomes widespread internationally and use the body part terms as the name of fighting techniques such as หมัด 'fist' ศอก 'elbow', เข่า 'knee', and the idiom that bring the body part term to reflect Thai boxing is มัดมือชก mát mu世 chók (bind-hand-punch) 'to force someone to do something'.

The idioms in Thai containing body part terms also reflect Thai way of living, for example, in the old time Thai people use the ladle made from coconut shell to scoop water in หน้างอเป็นตวัก nâa pen tawàk (face-become-ladle) or use threshing basket and หน้าบานเป็นกระด้ง nâa baan pen kradôy (face-bloom-become-threshing basket) 'to be delighted'. These things are rare in present especially in the city. Thai culture is rice culture. The idioms which reflect this fact are nâa khâaw tạ (face-rice crust) 'a scarred face' and ชุบมือเปิบ chúp mษ pəəp (soak-hand-eat) 'get advantages from others without any help; to reap what others have sown', which reveal the way of eating in the past time. People used their hands instead of using spoons. 


\section{References}

Goosens, L. (1995). Metaphtonymy: the interaction of metaphor and metonymy in figurative expressions for linguistic action. In L. Goosens (Ed.), By word of mouth: Metaphor, metonymy and linguistic action in a cognitive perspective. Amsterdam: John Benjamins. http://dx.doi.org/10.1075/pbns.33.06goo

Hilpert, M. (2007). Chain metonymies in lexicon and grammar. In R. Günter, K. Klaus-Michael, B. Thomas, \& S. Peter (Eds.), Aspects of meaning construction (pp. 77-98). Amsterdam: John Benjamins Publishing. http://dx.doi.org/10.1075/z.136.07hil

Johnson, M. (1987). The body in the mind: the bodily basis of meaning, imagination, and reason. Chicago: University of Chicago Press.

Lakoff, G., \& Johnson, M. (1980). Metaphor we live by. Chicago: University of Chicago Press.

Lakoff, G., \& Johnson, M. (1999). Philosophy in the flesh: the embodied mind and its challenge to western thought. New York: Basic Books.

Panther, K.-U., \& Radden, G. (Eds.). (1999). Metonymy in language and thought. Amsterdam: John Benjamins Publishing. http://dx.doi.org/10.1075/hcp.4

Radden, G., \& Zoltán, K. (1999). Towards a theory of metonymy. In K.-U. Panther, \& G. Radden (Eds.), Metonymy in language and thought (pp. 17-59). Amsterdam: John Benjamin. http://dx.doi.org/10.1075/hcp.4.03rad

Sweetser, E. (1990). From etymology to pragmatics: metaphorical and cultural aspects of semantic structure. Cambridge: Cambridge University Press. http://dx.doi.org/10.1017/CBO9780511620904

Vyvyan, E., \& Melanie, G. (2006). Cognitive linguistics: an introduction. New Jersey: Routledge.

Wongthai, N. (2012). Conceptual metaphors of death in Thai. Journal of Language and Culture, 31(1), 43-64. Research Institute of Languages and Cultures of Asia, Mahidol University.

Yu, N. (2009). From body to meaning in culture: papers on cognitive semantic studies of Chinese. Amsterdam: John Benjamins Publishing. http://dx.doi.org/10.1075/z.149

\section{Notes}

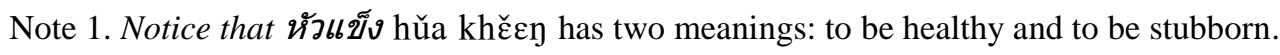

Note 2. หัวอ้ายเรือง hǔa Pâay rtan comes from a famous novel titled 'Daw Rueng' (Marigold) by Rosalalane (a famous writer in Thailand)

Note 3. คางเหลือง comes from fighting domain. In the past, when someone was punched at the end of the chin, they would be applied with wax mixed curmin as medicine. Therefore their chin would turn to yellow.

\section{Copyrights}

Copyright for this article is retained by the author(s), with first publication rights granted to the journal.

This is an open-access article distributed under the terms and conditions of the Creative Commons Attribution license (http://creativecommons.org/licenses/by/3.0/). 